УДК 316.77

ОСТАШКОВ Александр Валерьевич - кандидат экономических наук, доцент кафедры государственного управления и социологии региона Пензенского государственного университета (440026, Россия, г. Пенза, ул. Красная, 40; оаvrus@таі..ru)

МУРУНОВА Екатерина Валентиновна - старший преподаватель кафедры философии и социальных коммуникаций Пензенского государственного университета (440026, Россия, г. Пенза, ул. Красная, 40; ekva@mail.ru)

\title{
ВИЗУАЛЬНЫЕ КОММУНИКАЦИИ СОБЫТИЙНЫХ МЕРОПРИЯТИЙ В БРЕНДИНГЕ ТЕРРИТОРИИ
}

\begin{abstract}
Аннотация. В статье рассматриваются событийные мероприятия как инструмент укрепления и развития бренда территории. Поднимается вопрос о влиянии визуальных коммуникаций событийных мероприятий на продвижение территории и формирование ее знакосферы. Используя портфельный подход, авторы анализируют мероприятия, входящие в календарь событий Пензенской обл. на 2020 г., выявляют взаимосвязь территориальных символов и визуальных коммуникаций знаковых событийных мероприятий Пензенской обл.
\end{abstract}

Ключевые слова: визуальные коммуникации, территориальный брендинг, событийные мероприятия, портфель событий, событийный маркетинг

$\mathrm{H}^{2}$ а протяжении последних десятилетий брендинг территории остается темой научной и профессиональной дискуссии. В первую очередь это связано с тем, что бренд территории - сложная ментальная конструкция в сознании целевых аудиторий и включает в себя множество факторов. Более того, данное понятие находится на стыке целого ряда научных областей: экономики, юриспруденции, психологии, социологии, антропологии, культурологии.

Многие авторитетные специалисты посвятили свои работы брендингу территорий [Котлер 2005; Анхольт 2004; Динни 2013; Панкрухин 2006; Визгалов 2011; Важенина 2008; Родькин 2016; Василенко 2016].

Целью создания бренда территории является повышение ее привлекательности для инвесторов, туристов, высококвалифицированных специалистов, рост лояльности местных жителей к территории и местной власти, развитие культуры и бизнеса.

Обобщая ряд существующих определений, стоит подчеркнуть, что бренд территории состоит из материальных и нематериальных активов. К материальным активам можно отнести инфраструктуру, уровень сервиса, туристический продукт и т.д. К нематериальным - ассоциации, смыслы, репутацию, символы.

В современной практике продвижения сложилась ситуация, когда территория может иметь несколько брендов. Это обусловлено в первую очередь широким спектром задач, решаемых в рамках продвижения территории, и большим числом групп потребителей данной территории. Одним из направлений использования технологий брендинга в управлении территорией является решение вопросов, связанных с внутренним и въездным туризмом.

Территории, занимающие ведущие места на туристическом рынке, уже давно поддерживают и включают события в свою стратегию экономического развития и государственного строительства в качестве инструмента маркетинга и брендинга территорий. Событийный маркетинг - инструмент, кото- 
рый позволяет удерживать и привлекать посетителей и инвесторов. События важнейший мотивирующий фактор в туризме. Они заметно влияют на развитие, маркетинговые планы и конкурентоспособность территорий [Слогоцкий 2016: 97].

Визуальные коммуникации мероприятий формируют целостный образ события, идентифицируют его из множества мероприятий, схожих по тематике и форме проведения или проводимых на данной территории, - в них наиболее ярко выражена идея мероприятия.

Символика и визуальные коммуникации событийного мероприятия имеют сложную систему взаимодействия с брендом территории. Так, символика событийных мероприятий может временно выполнять функции идентификатора территории. Визуальные коммуникации могут интегрироваться с территориальным брендом, причем символика мероприятия может быть семантически напрямую связана с регионом, а может не иметь прямой территориальной привязки. Чаще всего в символике с территориальной привязкой присутствуют архетипичные образы территории: узнаваемые архитектурные сооружения, известные памятники, монументы, арт-объекты, персонажи (например, тамбовский волк, ласточка в Пензе), символы производств и ремесел данной территории и т.П.

Тенденция современных визуальных коммуникаций - абстрактная айдентика - не отражает и не создает прямых и предметных ассоциативных связей с территорией. Тем не менее абстрактная символика мероприятий формирует образ территории, ориентированной на молодое поколение, современные тенденции, динамичное развитие. Такие визуальные коммуникации характерны для событий, связанных с искусством, высокотехнологичными производствами, креативной индустрией.

Символика мероприятий, проводимых на территории, формирует совокупность различных по назначению и применению знаков-идентификаторов, принадлежащих одному региону, - так называемую знакосферу.

Событийные мероприятия играют важную роль в репрезентации территории, даже если территория не имеет собственного бренда.

Пенза и Пензенская обл. являются одними из немногих регионов на сегодняшний день, не имеющих бренда. Можно сказать, бренд территории складывается стихийно, в связи с чем влияние пользовательского опыта, полученного гостями событийных мероприятий, играет еще большую роль в формировании имиджа территории. Именно культурные мероприятия позволяют сосредоточить внимание аудитории на особенностях территории, ее истории, традициях, ее сильных сторонах как у гостей, так и у местных жителей.

Формирование и продвижение бренда территории посредством событийных мероприятий будет наиболее эффективным при использовании портфельного подхода. Суть данного подхода заключается в формировании портфеля событий, в который входят события разных видов, проводимые с разной частотой, различного масштаба, формирующие разнообразный пользовательский опыт участников и гостей мероприятия. Данный подход заключается в том, чтобы выработать стратегию взаимодействия событийных мероприятий между собой и с брендом территории. В рамках стратегии необходимо четкое представление о вкладе каждого событийного мероприятия в бренд территории. Комплексная оценка событийных мероприятий позволит оптимизировать структуру событийного портфеля, учитывая стратегию развития и позиционирования бренда территории, или (в случае Пензенской обл.) стать стратегическим инструментом продвижения территории, главным образом в области туризма.

Формирование календаря событий на сайте по туризму Пензенской обл. 
Welcom 2 Penza является первым шагом в создании портфеля событий. Календарь событий на 2020 г. содержит 89 событийных мероприятий разной тематики и масштаба. Просмотрев тематику, цель и форму проведения мероприятий, можно выделить культурные, образовательные, спортивные и деловые мероприятия. Политические мероприятия в календаре событий Пензенской обл. отсутствуют.

Большую часть календаря событий составляют культурные мероприятия - их 75. Почти половина, 32 мероприятия, - это мероприятия, связанные с национальными традициями и народным творчеством; 9 музыкальных фестивалей и конкурсов разной направленности, а также историко-культурные и реконструкторские события, гастрономические фестивали, литературные, театральные, посвященные изобразительному искусству события.

Календарь событий также включает в себя 6 образовательных, 5 спортивных и 3 деловых мероприятия. Стоит отметить, что большая часть спортивных событий, в т.ч. и федерального уровня, не вошли в данный перечень.

В календарь событий вошли и небольшие сельские праздники, которые проводятся для местных жителей, и уникальные мероприятия с богатой историей, которые достигли уровня событийного бренда.

Для первичного анализа влияния мероприятий в календаре событий и их визуальных коммуникаций на репрезентацию Пензы и Пензенской обл. нами была построена модель событийного портфеля, которая представлена на рис. 1.

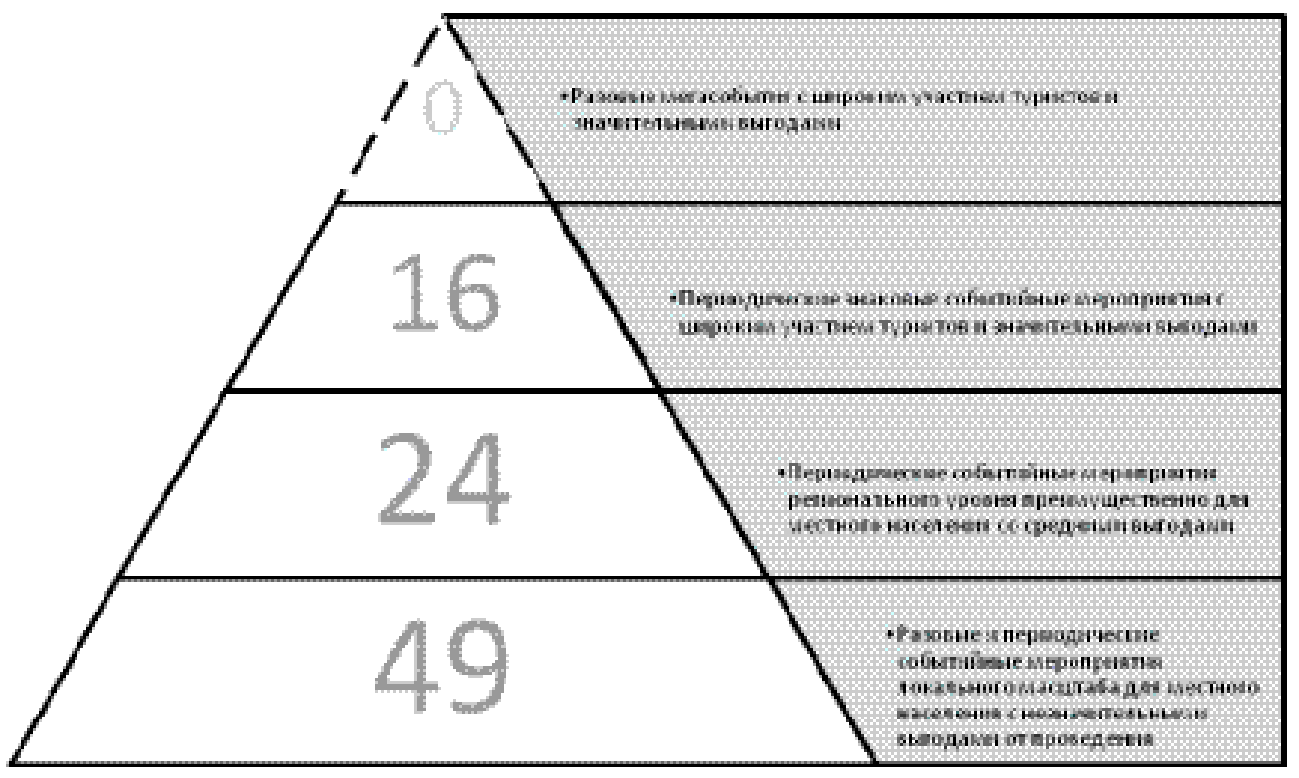

Рисунок 1. Модельная структура событийного портфеля Пензенской обл.

Модель составлена по работе А.Ю. Александровой [Александрова 2015: 148] с учетом особенностей специфики региона и мероприятий, представленных в календаре событий Пензенской обл.

В основании пирамиды находится группа, объединяющая периодические событийные мероприятия локального масштаба. Большая часть - сельские 
праздники. Многие из них не обладают аутентичностью, не имеют уникальных черт и направлены исключительно на местное население. Также в эту группу включены мероприятия, которые будут проводиться впервые и не могут пока оказать существенное влияние на формирование образа региона.

Несмотря на то что на сегодняшний момент выгоды от проведения данных мероприятий незначительны с точки зрения продвижения территории, есть ряд мероприятий с большим туристическим потенциалом. Примером служит мордовский национальный праздник коня «Тундонь Ильтема» в селе Большое Пермиево. Это не просто сельский праздник, позволяющий сохранять традиции мордовского народа, объединять односельчан. Это уникальное событие, которое при правильной упаковке и продвижении может стать привлекательным туристическим продуктом.

Более того, синергия мероприятий данной группы формирует образ Пензенской обл. как милой сердцу многих провинции, где бережно относятся к историческому наследию малой родины и культурным традициям русского, мордовского, татарского, чувашского народов.

Большинство мероприятий в этой группе не имеют специально разработанных визуальных коммуникаций и не влияют на формирование знакосферы территории. Стоит отметить, что все эти события, за исключением тех, что проводятся впервые, презентируются в сети Интернет посредством фотографий и видеоматериалов, но зачастую определить принадлежность визуальных материалов к конкретному мероприятию возможно только по тексту.

Второй блок пирамиды состоит из периодических событийных мероприятий областного уровня. Среди них мы можем выделить две большие группы. Первая группа - мероприятия, направленные на местное население и изначально не рассчитанные на привлечение туристов, но имеющие существенное значение для формирования образа территории. Примером может служить научный фестиваль для детей и взрослых «Витамин науки», открытый фестиваль предпринимателей «Наша кузница».

Вторая группа событийных мероприятий на сегодняшний день привлекает пусть и небольшой туристический поток, но она имеет значительное влияние на формирование бренда территории. Приводя пример, хотелось бы выделить широкую масленицу в Тарханах, всероссийский мотофестиваль «Кузнецкий рубеж».

Если рассматривать визуальные коммуникации событийных мероприятий, входящих в данный блок, то мы увидим, что большинство имеют собственную символику, подчас выполненную на высоком профессиональном уровне. Верхушка пирамиды - это периодические знаковые событийные мероприятия, привлекающие широкие туристические потоки и имеющие большое влияние на формирование имиджа города и области в целом. Сюда вошли событийные мероприятия, вошедшие в национальный календарь событий ${ }^{1}$ : межрегиональный историко-культурный фестиваль «ДаншиноFEST», купринский литературный праздник, межрегиональный фольклорный фестиваль «Купала в Золотаревке», межрегиональный литературный фестиваль «Белинская весна», Тихвинская ярмарка, а также крупные мероприятия с богатой историей, ежегодно увеличивающие число участников: международный фестиваль творчества и рукоделия «Канитель», всероссийский лермонтовский праздник, международный фестиваль джазовой музыки «ЈazzMay» и уникальное для России мероприятие - международный скульптурный и живописный симпозиум.

1 Национальный календарь событий. Доступ: http://eventsinrussia.com/ (проверено 20.05.2020). 
К знаковым событиям Пензенского региона также относятся всероссийские фестивали, такие как «Марсово поле», «Золотаревское городище - перекресток цивилизаций», Всероссийский кинофестиваль имени И.И. Мозжухина, всероссийский фестиваль театральных коллективов «Золотая провинция».

Особо отметим деловые событийные мероприятия: международную конференцию разработчиков программного обеспечения $S E C O N$, всероссийский форум в сфере медицинской промышленности и здравоохранения «Innomed», направленные, соответственно, на поддержку пензенских IT-кластера и кластера «БиоМед».

В этом же ряду мероприятий, не рассчитанных на привлечение больших туристических потоков, но играющих ключевую роль в формировании имиджа области и поддержке территориальных промышленных кластеров, стоит международный симпозиум по художественному стеклу и скульптуре «Хрустальное сердце России» в г. Никольске. Данное мероприятие является знаковым не только для области, но и для отрасли; традиционно участниками симпозиума становятся российские и зарубежные художники по стеклу. За последние годы в рамках мероприятия создан уникальный для России парк городских скульптур из стекла, который стал новой достопримечательностью г. Никольска и области в целом.

Знаковые событийные мероприятия вне зависимости от форм проведения влияют на формирование идентичности региона. Их символика не только является визуализацией идей и смыслов, вкладываемых в конкретное мероприятие, но и содержит элементы репрезентации территории. Стоит отметить, что символика и визуальные коммуникации восьми событий имеют территориальные привязки. Так, на логотипах фестивалей «Золотаревское городище - перекресток цивилизаций» и «Купала в Золотаревке» используется образ буртасского льва. Это уникальный археологический артефакт, изображенный также на гербе Пензенского района. В визуальных коммуникациях международного симпозиума по художественному стеклу и скульптуре, наряду с логотипом симпозиума, присутствует айдентика бренда «Никольск - хрустальное сердце России». Литературные события - лермонтовский праздник, купринский литературный праздник и «Белинская весна» - используют в визуальных коммуникациях изображение русских литераторов, связанных с местом проведения и концепцией мероприятия. Кинофестиваль «Мужская роль» использует в рекламных материалах образ И. Мозжухина, хотя стоит отметить, что логотип мероприятия не имеет территориальной привязки. Уникальным в рамках рассматриваемого вопроса является фестиваль в селе Даншино. В процессе подготовки и проведения фестиваля был разработан логотип села, который с незначительными изменениями используется как символика событий.

Деловые события - международная конференция разработчиков программного обеспечения $S E C O N$, всероссийский форум в сфере медицинской промышленности и здравоохранения «Innomed», а также фестиваль «JazzMay» и международный скульптурный и живописный симпозиум - имеют абстрактную айдентику, не имеющую территориальной привязки. Современные тренды в дизайне визуальных коммуникаций этих событийных мероприятий влияют на формирование более сложного образа территории, которая не только чтит и сохраняет традиции, но и динамично развивается в сфере культуры и инноваций.

На сегодняшний момент у двух знаковых событийных мероприятий Тихвинской ярмарки и фестиваля «Марсово поле»- отсутствует айдентика, а визуальные коммуникации не обладают ни уникальностью, ни территориальной привязкой. 
Стоит отметить, что в портфеле событий отсутствует кластер, объединяющий крупные, самые престижные международные события, обозначенные у Александровой как мегасобытия [Александрова 2015: 148] . Это связано со спецификой региона - события такого уровня в Пензенской области не проводятся.

Несмотря на то что событийные мероприятия имеют разную степень влияния на продвижение Пензенской обл., необходимо использовать весь портфель событий, что поможет транслировать преимущества региона на различные целевые группы, составить более полный портрет территории, привлечь к процессу формирования бренда местное население.

\section{Список литературы}

Александрова А.Ю. 2015. Интеграция событийных мероприятий в продвижение туристских дестинаций на принципах ко-брендинга. - Вестник Московского университета. Сер. 6. Экономика. № 6. С. 135-159.

Анхольт С. 2004. Брендинг: дорога к мировому рынку. М.: Кудиц-Образ. 324 с.

Важенина И.С. 2008. Имидж, репутация и бренд территории. - ЭКО. № 8. C. 6-8.

Василенко И.А. 2016. Возможности инновационных технологий территориального брендинга для формирования современного имиджа российских регионов. - Власть. Т. 24 № 1. С. 68-73.

Визгалов Д.В. 2011. Брендинг городов. М.: Институт экономики города. 324 с. Динни К. 2013. Брендинг территорий. Лучшие мировые практики. М.: Манн, Иванов и Фербер. 336 с.

Котлер Ф. 2005. Маркетинг мест: привлечение инвестиций, предприятий, жителей и туристов в города, коммуны, регионы и страны Европы. СПб: Питер. $134 \mathrm{c}$.

Панкрухин А.П. 2006. Маркетинг территории. СПб: Питер. 416 с.

Родькин П.Е. 2016. Бренд-идентификация территорий. Территориальный брендинг: новая прагматичная идентичность. М.: Совпадение. 248 с.

Слогоцкий Д.А. 2016. Событийный маркетинг как инструмент повышения туристической привлекательности территории. - Альманах теоретических и прикладных исследований рекламы. № 1. С. 96-99.

OSTASHKOV Aleksandr Valer'yevich, Cand.Sci. (Econ.), Associate Professor of the Chair of Government Control and Social Science, Penza State University(40 Krasnaya St, Penza, Russia, 440026; oavrus@mail.ru)

MURUNOVA Ekaterina Valentinovna, Senior Lecturer of the Chair of Philosophy and Social Communication, Penza State University (40 Krasnaya St, Penza, Russia, 440026; ekva@mail.ru)

\section{VISUAL COMMUNICATIONS OF NEWSWORTHY EVENTS IN TERRITORY BRANDING}

Abstract. The article deals with newsworthy events as an instrument for strengthening and developing a territory brand. It touches upon the influence of visual communications of newsworthy events on territory promotion and its symbols system formation. Using a portfolio approach, the authors analyze events, which are scheduled for the year 2020 in Penza Region, and identify interconnection of territory symbols and visual communications of significant newsworthy events of Penza Region.

Keywords: event marketing, event portfolio, visual communications, newsworthy events, territory branding 